\title{
Biblical Themes and Images in Faulkner's Novels
}

\author{
Xiamei Peng \\ School of Foreign Languages \\ North China Electric Power University \\ Beijing, China
}

\begin{abstract}
It is no exaggeration to say that religion exerts great influence on Faulkner and a lot of his fictions, which may be the key to the interpretation of his novels. This paper tries to exemplify the influence of Bible on Faulkner through the discussion of his narrative structure, theme, Christian characters, and images and symbols in his novels. By doing so, it is hoped to be able to offer a thorough and deeper understanding of Faulkner, and shed a new light on his works.
\end{abstract}

Keywords-religion; narrative structure; theme; images; symbols

\section{INTRODUCTION}

William Faulkner (1897-1962), one of the most eminent writers in the world and America as well, is not an easy writer to interpret. It is no exaggeration to say that whenever he is mentioned, what immediately appears in our mind is his fictional Yoknapatawpha County, which includes his major works such as The Sound and the Fury(1929), Light In August (1932), Absalom, Absalom! (1936). These three canonical masterpieces are the core of Faulkner's main achievement. They are also a brilliant beginning of Faulkner's profound illustration of the influence of religion on his work as a whole. As a matter of fact, in reply to interviewers' questions about his reading, Faulkner frequently claims the Old Testament as one of his favorite books, and that he reads it "once every ten or fifteen years."1 This is significant because many of his critics have hinted at the Biblical, the legalistic, elements in his work.

It is no wonder that religion plays a significant role in Faulkner's novels, especially Puritanism and Calvinism. He lives in the so called "Bible Belt", where for average Southerner, the Old Testament is vitally important. Therefore, Faulkner is, unavoidably and consciously, or unconsciously, influenced by its religious doctrines. When young William Faulkner was at his great-grandfather's house in Ripley, he had to recite a Bible verse before the meal would be served to him. That is a powerful incentive to absorb the features of a culture, willingly or not. Faulkner, in fact, has offered one of the best descriptions of the religious culture of his raising. "My life was passed, my childhood, in a very small Mississippi town, and that was a part of my background. I grew up with that. I assimilated that, took that in without even knowing it. It's just there. It has nothing to do with how much of it I might believe or disbelieve-it's just there."2

\footnotetext{
${ }^{1}$ Robert A. Jellife, ed., Faulkner at Nagano, 42.

${ }^{2}$ Frederick L. Gwynn and Joseph L. Blotner, Faulkner in the University:
}

Not surprisingly, Faulkner's literary imagination is based on the framework of Southern religion. It is widely acknowledged that he frequently uses Biblical allusions and images in his novels and borrows ideas from the Bible.

Surprisingly, Faulkner also strikes a path to become a Modernist writer and put himself under the influence of Modernism. In the turmoil of the late 1920s, literary circle in American South is experiencing a revolutionary movement called Southern Renaissance. During this historical period, the clashes among American social classes are particularly intense, which not only shows the struggle of religious matters, but also the issues of ethnicity, gender, emerging contradictions between modern business concepts and traditional moral values. This social trend results in the distortion and alienation of human nature, thus calls for a review of history and reality. William Faulkner is inevitably stumbled into this social and literary movement and some of his works are clearly a reflection of this dilemma. As a result, Biblical images and symbols, combined with the influence of this social trend, are pervasively employed in his novels to express his concern, care, worry, questioning and accusation of the people and place he deeply loves.

\section{ANALYSIS OF FAULKNER's NOVELS}

Faulkner's novels are permeated with Biblical images and symbols, which showcases the close connection between his works and the Bible. Apart from that, he also borrows a U-shaped narrative structure to tell his stories, which is very typical in Biblical narration. To depict his characters, Faulkner still puts them under the influence of the Biblical figures, reflecting or representing some of the characters from the Bible, thus telling his readers the underlying meaning of his stories. In the following parts, these three aspects will be discussed case by case to illustrate the points.

\section{A. Biblical Narrative Structure in Faulkner's Novels}

In his benchmark work, The Great Code: the Bible and Literature, Canadian literary critic, Northrop Frye, points out how the Bible and literary works exert effects on our inner world and spirit and that the Bible has frequented the use of a U-shaped narrative structure: "after people betrayed God, they suffered disaster and enslave. Then people regret and understand. Finally, people were saved at the previous level before they degenerated. This $U$ structure is the standard comedy structure. We can consider the Holy Bible as a holy

Class Conferences at the University of Virginia, 1957-1958, 41. 
comedy. It contains such a $\mathrm{U}$ narrative structure: at the beginning of Genesis, people lost the tree of life and the water of life; they obtain them in the revelation. In the middle part, it's the story of Israel.” (Northrop Frye, 220)

Likewise, we can find this U structure almost everywhere in literary works, which can be called the original narrative structure or the standard comedy. Conversely, an inverted U structure is called the standard tragedy. In Faulkner's works, there also exist these two kinds of narrative structure: $U$ narrative structure and the inverted U structure.

In Light in August, a typical U narrative structure is represented by Lena's story while the inverted structure is Joe Christmas. In this novel, the beginning and ending is set on the country road, while the middle part is her experience in the town called Jefferson. By means of creating this setting, Faulkner wants to convey the meaning that country roads are the symbol of an ideal living condition. Like the structure in the Bible, at the beginning of Genesis, people lost the tree of life and were driven out of the Eden; then they obtained both in the Revelation. In the middle part, it is the story of Israel, which is a story about pain and punishment. Only God can save them from their sufferings. So it is quite common to find in the Bible that at first, the Israelites commit sins, and then God punishes them by means of natural disasters or invasions from neighboring tribes or countries. Only then do the Israelites realize the reasons and source of their sufferings, so they bow and kneel to God and ask for relief. In the end, God saves them from their pain and punishment and destroy those who inflict His chosen people. For Faulkner, Jefferson is controlled by Puritanism that suffocates people's free will and spirits, and only when Lena goes back to the country road can she get a free and happy life. Therefore, her experience in Jefferson, like the punishment in the Bible, is at the bottom of the $U$ narrative structure. In this way, Faulkner parodies the Biblical U structure in Lena's story to express his antiPuritanism and more importantly, create a comic effect on this novel. In contrast, Joe Christmas' story is an inverted U structure. The beginning and ending of his life and story happens in the town of Jefferson, while the highest point and the most peaceful time of his life is when he leaves town and goes into the field. Joe Christmas' story is a standard tragedy, which, to some extent, parodies the life story of Jesus Christ. At the beginning of his story, he came to the town Jefferson, then he recalls his miserable childhood, being mistreated by people around him, including his grandfather, and his adoptive father. In Jefferson, he kills Miss Burden out of fear of being loved and controlled by her. For the crime he commits, he has to run away to the wild, where he finds peace in his inner self. At the end of his story, he returns to Jefferson to find redemption and reconciliation with people, although this ends with his torture and being lynched by his capturers. Unlike Lena Grove, Joe Christmas' turning point is his leaving Jefferson and going to the woods. After this turning point, he falls to the bottom of his life, that is, being captured and lynched. His inverted $U$ structure reveals Faulkner's deep sympathy toward Joe Christmas and his harsh criticism to Puritanism.

\section{B. Biblical Themes in Faulkner's Novels}

As a voracious reader of the Bible, Faulkner borrows more than words or phrases from it, but more importantly, he parodies the theme of some Biblical stories, which enables him to have a deeper insight into his own works.

In Absalom, Absalom!, Faulkner recounts the story of an American type, a self-made man. "Using the mythic language of the Judaeo-Christian creation narratives, Faulkner depicts Thomas Sutpen's settling of a plantation in the wilderness of early nineteenth-century Mississippi as an act of hybris that engenders a series of tragic consequences spanning generations." ${ }^{3}$ In Absalom, Absalom!, Faulkner "makes deliberate use of the imagery and rhetoric of the Biblical account of the Judaeo-Christian creation myth." 4 The creation theme is not incidental to the statement made by the novel. Instead, the inverted creation myth with which the novel begins is central to the Sutpen story. All other narrators in the novel revolve around Sutpen's narrative. Faulkner uses creation imagery and theme to comment on "Sutpen's pretentious self-creation and his ironically destructive creation of the domain of Sutpen's Hundred." ${ }^{5}$ The original creation occurs in Genesis, which is a theological reflection on the theme of creation. It functions as a reference point for human attempts to achieve order. In sharp contrast, Faulkner employs the story of creation as a vantage point for critiquing Sutpen's pretensions and for explaining their inevitable destructiveness. In contrast to the divine Creator, Sutpen is a demonic creator and his demonic energy that drives him to create his plantation is the one that also subverts his act of creation.

In the Genesis Creation story, God sees through the trackless void and shapes it by means of creative word. Like the God of Genesis, Sutpen is one who creates "out of the soundless Nothing"6. This is a recurrent image in Absalom, Absalom!. Later in the novel, Sutpen builds his house "apparently out of nothing"7 . Later again, after Sutpen's Hundred has been built, Sutpen and his horse came to Jefferson "as though they had been created out of thin air." However, Sutpen's creation is in ironic contrast to the divine creation in Genesis. Whereas the God establishes order and harmony on earth, Sutpen causes chaos and disorder that is to span to following generations. All these images and biblical theme is to point to one of the underlying preoccupations of the novel, that is, the relationship between humanity and nature.

\section{Christian Characters in Faulkner's Novels}

There are quite a few characters in Faulkner's novels that clearly carry the image of Biblical figures, and at the same time, reflects his attitude towards his characters in particular and the society in general.

\footnotetext{
${ }^{3}$ William D. Lindsey, "Inversion of Judaeo-Christian Creation Myth", in Faulkner and Religion, edited by Doreen Fowler and Ann J. Abadie, 86. ${ }^{4}$ Ibid, 86.

${ }^{5}$ Ibid, 86

${ }^{6}$ William Faulkner, Absalom, Absalom!, 8.

${ }^{7}$ Ibid, 11.

${ }^{8}$ Ibid, 32.
} 
Accruing to some critics, Lena Grove, in Light in August, represents the image of Virgin Mary and Byron Bunch who has been helping her is the symbol of Joseph. In the story, she wears blue which is the color of the Virgin Mary, and she also, like Mary, takes a palm fan. We can see from the plot that Lena's pregnancy and finding her baby's father coincides with Virgin Mary's receiving the Holy Spirit and getting pregnant. Like Mary from the Bible, Lena is shining with natural simplicity, kindness, perseverance, optimism and selflessness. Apart from this, She is also the specific symbol of the glory of "light in August". In the first place, her family name "Grove" means trees, which implies life. Her pregnancy and her determination to find her baby's father fit the image of forest goddess. Faulkner also intends to reflect the image of mother earth. Goddess of the earth is the Goddess of reproduction, a symbol of fertility, reproduction; and Lena Grove embodies the meaning of life, peace and physical health.

Again in Light in August, Faulkner, controversially but purposely, intends to create Joe Christmas as the modern Jesus Christ. There are some evidences of this intention we can easily find from the novel. In the first place, their initials J. C. are the same. Besides, both are betrayed by someone for money-Judas for 30 silvers and Lucas for 1000 dollars. Even the traitors' spelling of names are quite alike, one is Judas, the other Lucas. Still, when they died, both are at the age of 33 and both are laughed at and tortured to death. Literally, the reasons of the execution are different, but metaphorically, the real cause of their deaths is about identity, their uncompromising belief about their identity and their differences from others and the outside world. In the final moment of Joe Christmas, he gives up his gun and let people capture him and torture him. The gun symbolizes human power and the giving up of his gun implies his forgiveness to the people around him, which is also a reflection of Jesus Christ in his final crucifixion.

Similarly, the idiot Benjy Compson is also, in a sense, to be identified with the story of Jesus Christ ? Firstly, he is the man things are done to, which means like Jesus Christ, people around him don't understand him, but are afraid of him. The only thing they can do is to ask an outsider to murder or castrate him. By so doing, people feel that they have been rid of the dangers or threats posed by the unknown of Jesus Christ or Benjy Compson. Moreover, Jesus Christ was 33, when he was crucified; and not surprisingly Benjy was also 33 when he was castrated. Finally, Benjy, like Jesus Christ, forgives those who have hurt him and find peace in a black people's church, which indicates that Benjy finds salvation from God.

From Absalom, Absalom!, readers can find the parallels between the story of Thomas Sutpen and the Biblical account of the house of David in Second Samuel. It is these parallels that provide a historical critique of the concept of dynasty that Sutpen's "design" assumes and, in so doing, provide the book with its thematic center. The choice of its title (from Second Samuel 18:37) were "simultaneous". 9 Aside from the

${ }^{9}$ Frederick L. Gwynn and Joseph L. Blotner, Faulkner in the University: Class Conferences at the University of Virginia, 1957-58, 76.
Biblical title, there are a lot of Davidic parallels to the story of Thomas Sutpen, for example, David's rise to kingship is, in many ways, parallels Sutpen's rise, and David's unhappy later days suggest many of the horrifying events that bring Sutpen's dynasty to its destruction. All these prove the timelessness and universal quality of the Sutpen's story and its superiority to the general Southern Gothic. David's sin against God leads his failure in his late days, and likewise, Sutpen's wrong doing toward his first wife makes him suffer. His son, Bon, like David's son Amnon, commits incest with his sister, Judith. Henry, Sutpen's son from his second marriage, killed Bon to revenge for his sister, which is totally in line with Absalom's design to kill Amnon. All these complicated stories coincide with each other, creating coherence and historical parallel between David's house and the house of Sutpen. By so doing, Faulkner enlightens his readers the truth that "Sutpen's story is the story of the nation: in critiquing Sutpen's achievements, Faulkner is implicitly questioning the myths by which the American people live." 10

\section{Images and Symbols in Faulkner's Novels}

It is widely acknowledged that image and symbol are two very important frequently used concepts in literary works. According to Leland Rycken, image is a word which defines a thing (such as a tree or a house) or an action (such as run), while symbol is an image which contains some other meanings besides its own meaning. In this sense, all the things or actions we can imagine are images, while for symbols, as Rycken defines, a "symbol is the further meaning beyond image's material level. In a culture, symbol appears with the common language, i.e. Bible would not create a symbol for a certain situation." (Rycken, Wilhoit and Longman, 725) In the following analysis, two important images in the above mentioned four canonical novels will be discussed concerning their biblical meanings, which is a solid proof that Faulkner not only borrows a lot from the Bible but also that the Bible has a tremendous influence on him.

1) The Image of Fire in Faulkner's Novels: The image first covered here in this paper is fire, which bears the meaning of destruction and purification. Fire is believed, according to the Bible, to have the power to drive away and purify all evils and decayed things by means of burning. Only after the evil things have been burned down, new and beautiful things can survive and submerge. For example, offerings for God have to be burnt, so that God can appreciate and enjoy them. Also, fire has the power to hurt or even kill people. In Isaac' story, God put a trial on Abraham to see if he is obedient and loyal to Him, so he asked Abraham to sacrifice his only son Isaac in the fire. Abraham passed the test and Isaac was not burned, instead a goat was offered in his place to God. Another example of fire's multi-layer of meaning can be seen from Moses' story:

${ }^{10}$ William D. Lindsey, "Inversion of Judaeo-Christian Creation Myth", in Faulkner and Religion, edited by Doreen Fowler and Ann J. Abadie, 86. 
3:2 There the angel of the LORD appeared to him in a flame of fire out of a bush; he looked, and the bush was blazing, yet it was not consumed. 3 then Moses said, "I must turn aside and look at this great sight, and see why the bush is not burned up."11

Here God makes the bush burn up but not consume, which is a miracle God makes to show Moses that he has the ability to control any power in the world, even the destructive and deadly fire. By so doing, God tries to persuade Moses to obey and serve him and follow his instructions.

Furthermore, fire is also a way to communicate with God, because God once told Moses (Exodus 20: 24): "You need make for me only an altar of earth and sacrifice on it your burnt offerings and your offerings of well-being, your sheep and your oxen; in every place where I cause my name to be remembered I will come to you and bless you. ..."

Still, fire can be used as a means of atonement and conveys the meaning of holiness. This can be seen from all kinds of burnt sacrifices and rituals. For example, in Exodus 29: 13-14: "You shall take all the fat that covers the entrails, and the appendage of the liver, and the two kidneys with the fat that is on them, and turn them into smoke on the altar. 14 but the flesh of the bull, and its skin, and its dung, you shall burn with fire outside the camp; it is a sin offering." Also in Exodus 29: 25: "Then you shall take them from their hands, and turn them into smoke on the altar on top of the burnt offering of pleasing odor before the Lord; it is an offering by fire to the Lord."

In Faulkner's Light in August, fire serves as an important image to mean destruction and rebirth. After Joe Christmas kills Miss Burden, he set fire on her house. Here fire, on the one hand, means death and destruction, the death of Miss Burden and also causes the death of Joe Christmas because of his crime. On the other hand, fire also means rebirth of Miss Burden and Joe Christmas. Only after their deaths, they have the chance to be reborn and have a new life.

2) The Image of Water in Faulkner's Novels: Water is another frequently used and discussed image in the Bible, which bears significant underlying meanings to Bible readers. As a matter of fact, in the Bible, water is an image which conveys a profound and crucial significance. In the Old Testament, at the beginning of Genesis: "And God said: 'Let the water under the heaven be gathered together unto one place, and let the dry land appear.' And it was so."12 Then in Genesis 2:10, it says: "A river flows out of Eden to water the garden, and from there it divides and becomes four branches." So in this sense, water is the source of life and security. However, quite contradictorily, the image of water also has the meaning of destruction, as we can read from the Bible that God determined to destroy the earth with the Great Flood since people on earth were wicked and did,

\footnotetext{
${ }^{11}$ Exodus 3: 2-3.

${ }^{12}$ Genesis 1:9.
}

in God's eye, wicked things. So the flood destroyed everything on earth and "everything on dry land in whose nostrils was the breath of life died." ${ }^{13}$ Using the flood, God clears and cleans the evils from the earth, so water also conveys the meaning of cleaning up evils from the world and building a better one. Later when Moses led the Israelites our of Egypt, they were short of water, so God asked Moses to strike a rock and water came out of it. Thereby, water represents the source of survival, life and God's miracles.

Similarly, water is also an important image in the New Testament. But in contrast to Old Testament, the New Testament focuses more on the symbolic meaning of water-salvation. "And when Jesus had been baptized, just as he came up from the water, suddenly the heavens were opened to him and he saw the Spirit of God descending like a dove and alighting on him." 14 The symbol of salvation can be clearly seen from this part. After Jesus came out of the water, the heaven is opened, which means Jesus Christ can save Christians and take them to the heaven.

In Faulkner's novels, water is frequently used as an image to convey Biblical meanings to the stories and symbolize certain underlying messages to the reader. Like in Light in August, after Joe kills Burden, his inner world is full of turmoil, so he runs away all along the river to find peace. Then he sits against a tree beside a spring, feeling quite peaceful. The clarity of water cleans his inner world and the tree makes him feel safe. "He patiently puts the cold and hard water on his face", which he thinks is to make him much more sober. Faulkner uses the two adjectives "cold and hard", which indicates that Joe is not a cold and merciless person. Using this detail, Faulkner intends to tell readers that Joe wants to save himself, clean his soul and begin a new life by means of washing himself with clear water. All the way through his escape from the town to the wild, he always cleans himself up, meaning that he washes his soul with clean water. It is a touching moment that transmits the meaning that Joe Christmas, at the end of his life, enjoys the beauty of nature and purity of life.

In his masterpiece novel, The Sound and the Fury, the image of water also has several layers of meanings. Like what we can find from the Bible, water and tree are related images, in The Sound and the Fury, they are also closely connected. Water can clean Caddy and makes her smell like the scent of tree. In this sense, water is regarded as an image to clean up sins and evils, and at the same time it is also an image of redemption. In the novel, the first time when Caddy wears her mother's perfume, Benjy cries wildly. It is not until Caddy cleans it off and "smells like a tree" does he stops crying. Then after Caddy kisses a man, Benjy again cries and demands her to clean her mouth until she "smells like a tree." Finally, when Caddy loses her virginity, Benjy pushes her to the bathroom upstairs, hoping that she can be the same Caddy and "smells like a tree" again. All these three scenes are centered on the image of water and its underlying meaning of cleasing the sins and evils, and also

\footnotetext{
${ }^{13}$ Genesis 7:22.

${ }^{14}$ From Matthew 3: 16, New Testament.
} 
the implication of rebirth. In Benjy's mind, water can clean off Caddy and her faults, which bears a similar significance to the baptism for Christians. Apart from this image, water is also served as a demonic image in this novel. Benjy recalls an incident in his childhood that a group of children played in "the branch and Caddy squatted down and got her dress wet" 15 and then "Caddy took her dress off and threw it on the bank. Then she didn't have on anything but her bodice and drawers, and Quentin slapped her and she slipped and fell down in the water. When she got up she began to splash water on Quentin, and Quentin splashed water on Caddy." 16 Here the wet dress symbolizes Caddy's degeneration, losing her virginity, which should and will be punished, as one of the characters said, "Your mommer going to whip you for getting your dress wet." ${ }^{, 17}$ For Quentin, water is a symbol of death, which frequently appears in his monologues. In the end, he chooses to drown himself in the water, which signifies his intention to die and his hope to embrace rebirth.

\section{CONCLUSION}

On the basis of the discussion above, it is reasonable to make an affirmative conclusion that a coherent system of religious values and thought inform Faulkner's novels. It may not be immediately apparent literally, but actually, humankind's consuming yearning for God is never absent or doubted in his fictions. It thus makes sense that his fictions focus not so much on God, but on a human aspiration to the divine. Throughout his fictional career, Faulkner relentlessly explores this human quest for God, and on some occasions, exposes a darker side to mankind's immortal longings, as what we can see from Light in August. In Faulkner's later works, this search for God seems to take an inward turn and ultimately, it seems to people that what Faulkner tries to advocate is the fact "that religion should be human- rather than God-centered, that religion should serve humanity.",18 This may be the key to better understanding the religious meaning in Faulkner and his novels.

\section{ACKNOWLEDGEMENT}

This article is supported by "The Talent Cultivation Project for Colleges and Universities issued by Beijing". Project No.:GJ2015065.

\section{REFERENCES}

[1] Jellife, Robert A., ed., Faulkner at Nagano. Tokyo: Kenkyusha, 1956.

[2] Frederick L. Gwynn and Joseph L. Blotner, Faulkner in the University: Class Conferences at the University of Virginia, 19571958. Charlottesville: University Press of Virginia, 1959

[3] Lindsey, William D. "Inversion of Judaeo-Christian Creation Myth", en Faulkner and Religion, edited by Doreen Fowler and Ann J. Abadie. Jackson: University Press of Mississippi, 1991.

[4] Faulkner, William, Absalom, Absalom!. London: Vintage Books, 2005

\footnotetext{
${ }^{15}$ William Faulkner, The Sound and the Fury, 17.

${ }^{16}$ Ibid, 18 .

${ }^{17}$ Ibid, 17.

${ }^{18}$ Doreen Fowler, Introduction to Faulkner and Religion, X.
}

[5] Rycken, Leland, James Wilhoit, and Tremper Longman III. Dictionary of Biblical Imagery. Downers Grove: Inter Varsity Press, 2010.

[6] Frye, Northrop. The Great Code: The Bible and Literature. New York: Harcourt Brace Jovanovich Publishers, 1982.

[7] Faulkner, William. The Sound and the Fury. New York: Random House, 2012.

[8] Doreen Fowler, "Introduction", en. Faulkner and Religion, edited by Doreen Fowler and Ann J. Abadie. Jackson: University Press of Mississippi, 1991. 